\title{
Barents region transition to a green economy
}

\author{
Anton Shcherbak ${ }^{1, *}$, Sergey Tishkov ${ }^{1}$, and Valentina Karginova-Gubinova ${ }^{1}$ \\ ${ }^{1}$ Karelian Research Centre of the RAS, 50, Al. Nevsky Prospect, 185030, Petrozavodsk, Russia
}

\begin{abstract}
The article addresses the development of a green economy through the prism of renewable energy. Currently, interest in the development of renewable energy is growing dramatically, as evidenced by the highest growth of renewable energy among all energy sources in the world balance. The aim of this article is to carry out the quantitative assessment and to estimate economic potential from introduction of promising energy-saving and energy-efficient technologies, new energy sources. This paper considers the energy sector through the renewable energy sources, with a particular focus on the Barents region in view of its specific. The article gives a brief overview of the main types of renewable energy sources in this territory. The article is completed with the evaluation of the energy potential in Russian part of the Barents region.
\end{abstract}

\section{Introduction}

Over the past decade, the global economy has received a particularly active impetus for the transition to a green economy. Over the years, the economies of entire states have been actively developing and transforming. Thus, the green economy has become one of the main development trends not only in individual countries, but in the whole world. Each country has set its own targets and developed roadmaps to achieve them. In general, this trend is typical for most countries of the world. This can be seen in the development of green energy and the gradual transition from traditional energy based on fossil fuels to renewable energy. Over the past twenty years, the increase in the total consumption of primary energy resources was 1.5 times, while the increase in the use of renewable energy was 5 times. However, this is only a small fraction of the potential of renewable energy.

In fact, the global trend towards greening the world economy has led to a pooling of efforts by states within the United Nations, the European Economic Community and other organizations. In many countries of the world the basis of energy strategies is the development of renewable energy as a line of state policy. Currently, scientific and technical programs for financing in the field of renewable energy exceed 1 billion dollars. Normative and legislative acts are adopted. Stimulation of the introduction of renewable energy sources into economic circulation is carried out by a whole range of measures. Basically, they boil down to subsidies, preferential taxation and preferential tariff system. At the state level, activities for the development of renewable energy are positioned not only as greening the economy, but also as increasing energy and economic security. This is due to the fact that recently energy based on fossil fuels has become a lever of political

${ }^{*}$ Corresponding author: scherbaka@mail.ru 
influence of some states on others, which, of course, does not contribute to the safe and dynamic development of both an individual state and the global world as a whole. For example, the EU plans to bring renewable energy up to one third of total energy consumption by 2050 [1].

Northern Europe is a key region for the development of the global economy. This is primarily due large reserves of natural resources which are concentrated in this territory. Among which the main stock of Europe minerals are iron, zinc, nickel, lead, gold, silver and many others. Moreover, most of the Barents region's natural resources are concentrated in the Russian part (Murmansk oblast, the Republic of Karelia, the Arkhangelsk region, the Komi Republic and the Nenets Autonomous Okrug). The unique natural and climatic conditions of the Barents region make this territory one of the main suppliers of wood and fish to European markets.

In the Barents region, large investments are made in the development of renewable energy, especially in wind, hydro and wave energy. Currently, Norway, Sweden and Finland have achieved the greatest success in this direction. In these countries, the share of renewable energy reaches $50 \%$ or more of gross energy consumption. The same investment policy in the Russian part of the Barents Region can bring similar results in the medium and long term.

\section{Materials and methods}

The energy system is a dynamically developing system, however it is still based on traditional energy sources - fossil fuels (coal, oil and natural gas). According to BP statistics in 2000, the total consumption of energy resources in the world amounted to 9.3 billion tons of oil equivalent, while the share of each type of energy source was: oil $-40 \%$, solid fuel $-28 \%$, gas $-20 \%$, nuclear energy $-5.6 \%$, hydropower $-6 \%$, renewable and other resources $-0.4 \%$ ). In 2020, global energy consumption increased and exceeded 14 billion tonnes of oil equivalent [2].

The use of fossil fuels in the energy sector has a negative impact on the environmental situation (air pollution, greenhouse gas emissions, etc.). According to estimates by the World Energy Council, while maintaining the current pace of extraction of fossil energy sources, their reserves will run out in the foreseeable future ( 850 years for coal, 270 years for natural gas, 180 years for oil). In fact, it suggests that future generations may be left without these resources. These and other problems can be solved by means of the use of renewable energy based on solar, wind, water and other sources. Energy from these sources is already actively entering our modern life, and sometimes partially or completely replaces traditional energy [3].

Bioenergy, wind power, hydropower and solar energy in the Barents region were studied as the main sources of renewable energy. Due to the quantitative and qualitative parameters for traditional energy sources (see table 1), comparisons with various sources of renewable energy were made.

Table 1. Heating values of some common fuels [4].

\begin{tabular}{|c|c|c|c|}
\hline Fuel & unit & kcal & MJ \\
\hline Dieselfuel & 1 liter & 10300 & 43.12 \\
\hline Oil & 1 liter & 10500 & 44.00 \\
\hline Naturalgas & 1 cubicmetre & 8000 & 33.50 \\
\hline Methane & 1 cubicmetre & 11950 & 50.03 \\
\hline Coal & 1 kilogram & 6450 & 27.00 \\
\hline Wood & 1 kilogram & 3400 & 14.24 \\
\hline
\end{tabular}


In the European North of Russia, as well as in its rest, the share of renewable energy saving in comparison with the developed countries is very small. This territory is characterized by a low level of energy infrastructure development, high wear and tear of electrical networks, and a high dependence on energy and energy supplies from outside its territory. These factors negatively affect development of territories and threaten energy and economic security of certain regions and the state in general [5].

Use of renewable energy saving can provide functioning of life support systems and to become a good impulse of development of territories where there is no created power network. At the same time in the regions having the centralized power supply system, the renewable power is capable can lower significantly expenses, to provide diversification of sources.

Among regions of the European North of Russia there are also areas where there is no created power network, and in what at the existing centralized power supply system of expense of end users are very high. Such region as the Republic of Karelia, in a critical measure depends on electrical supplies from the next subjects, however has the considerable potential of power generation at the expense of local types of fuel and renewable energy sources.

\section{Results and discussion}

The Barents region is currently the most efficient renewable energy sources are biomass, wind and water energy, and solar energy.

Biomass energy. The northern European countries have the largest forest landin the EU. The share of Sweden and Finland is up to one third of all forest land of the countries of the European Union. Finland and Sweden rightfully lead the EU on the volume of forests in their territories. In this countries forest holds about $52 \mathrm{mlnha}$. Finland is a lead in terms of the number of forests area per inhabitant of 4.6 hectares. In Sweden this indicator is 2.9 ha, Norway -1.6 ha [6].

On the other hand, the Russian part of the Barents region (Republics of Karelia and Komi, Arkhangelsk and Murmansk Oblasts) the largest part of the forest resources. Total forest land in the Barents region is more than $100 \mathrm{mln}$ ha. Forest resources are distributed as follows: Sweden part amounts to about $600 \mathrm{mln} \mathrm{m3,} \mathrm{Finland} \mathrm{part} \mathrm{amounts} \mathrm{to} \mathrm{about} 730$ mln m3. Russian part of forest resources of the Karelia, Komi, Murmansk and Archangelsk regions amount up to 6 bln $\mathrm{m} 3$ [6].

In the countries of the Barents region, the woodworking industry is quite well developed. At the moment in Northern regions of Russia (the Republic of Karelia and the Arkhangelsk region) there is a lot of work on transfer of a part of boiler houses to local fuel: peat, woodworking waste, etc. First of all, this is due to the fact that the woodworking industry is developed in these regions and there are significant volumes of woodworking waste (see table 2).

Table 2. Woody biomass estimation in the North-West region of Russia [7].

\begin{tabular}{|c|c|c|}
\hline Wasteofwoodworking & $\begin{array}{c}\text { Volume. } \\
\text { mln. m3/year }\end{array}$ & $\begin{array}{c}\text { Energy equivalent. } \\
\text { mln. tons of oil }\end{array}$ \\
\hline woodwaste & 10.0 & 1.74 \\
\hline loggingwaste & 45.3 & 7.94 \\
\hline total & 55.3 & 9.68 \\
\hline
\end{tabular}

In Finland peat and wood waste account for up to a quarter of total energy consumption. In Norway only $6 \%$ of total energy covered by bioenergy. The leading of use bioenergy is Sweden. In Sweden around 50\% of heating energy goes from wood. In addition, in the EU country of the Barents region, waste resource is actively used for energy production by 
burning and biogas producing. In Russian part of Barents region is a huge potential for biogas production, first of all it belongs to the enterprises in the sphere of agriculture, but nowadays unfortunately this potential is not used at all.

As an example only in St. Petersburg, about 5 million cubic meters of household waste are generated annually. At one of the largest solid waste landfills "Volkhovsky" the amount of produced methane will allow the power plant with a capacity of $2 \mathrm{MW}$ to operate for 2025 years [8]. In Russia, up to 3.5 billion tons of waste is generated annually, of which solid household waste is about 50 million tons (in the North-West Federal District volume of solid household waste is about 5 million tons). It was found that from 1 ton of municipal solid waste, you can get up to $200 \mathrm{~m} 3$ of biogas (of $100 \mathrm{~m} 3$ of pure methane) [9]. Thus, annually up to 5 billion $\mathrm{m} 3$ of pure methane can be produced, which corresponds to 7.47 billion $\mathrm{m} 3$ of natural gas or 5.69 million tons of oil (see table 1).

Wind energy. The Barents region has great potential for generating based on wind energy. The geographical position is such that most of this territory is located near the seas and oceans, as well as the mountainous terrain. Territories with open terrain always have the greatest wind potential, which is associated with the unhindered movement of the air masses, wherein wind speed is naturally enhanced specially in mountainous areas. Until recently, the main demand for electric energy in the countries of the Barents region (Finland, Sweden, Norway and Russia) was covered by nuclear energy, hydropower, as well as fossil fuels. Wind power used only a small part of its potential.

At the turn of 2010, the total capacity of wind generators was approximately $2100 \mathrm{MW}$ and was distributed as follows: Russia - 20 MW, Finland - 147 MW, Norway - 423 MW and Sweden - 1475 MW [10]. In EU countries of Baltic regions nowadays realized many new wind energy projects. As result of this the volume of wind energy increased more than 5 times and as of 2019 reached up to $11000 \mathrm{MW}$.

Potential of use of wind power in the Russian part of Barents region is estimated as considerable. In spite of the fact that wind energy in Russia is distributed not evenly, the part of territories where there is no centralized power supply has considerable resources of wind energy.

Rational use of the distributed wind potential allows using it both in autonomous wind power installations and during the work of wind turbines as a part of local power systems. The total wind potential of Russia is estimated at 80,000 million MWh / year, economic 40 million MWh / year [11]. According to the National Cadastre of Wind Energy Resources of Russia, the technical potential of the wind power of the North-West Federal District is 1785 billion $\mathrm{kWh} /$ year [12]. Favorable wind conditions for wind power are located in the waters of the Barents Sea, Kara Sea and White Sea coast, Lake Ladoga end Onega, as well as the Gulf of Finland. In the Republic of Karelia, by 2020, it is planned to be commissioned a $60 \mathrm{MW}$ wind power station on the coast of the White Sea [13].

Hydropower energy. One of the main advantages of hydropower is the capacity to control the amount of energy produced. Along with the ability to consistently receive the specified volumes of generated energy, hydropower makes one of the attractive sources of renewable energy. Hydropower plays a significant role in the Barents region. In 2007, 70 $\mathrm{TWh}$ of power were produced in this area at hydroelectric power plants. Unfortunately in Finland, Sweden and Norway, almost all the potential for using hydropower has been exhausted. An increase in the generation volume is possible only through the modernization of the hydroelectric power plants themselves and the installation of more powerful generators on them. This could potentially increase electricity generation by one third.

In the Russian part of the Barents region, hydropower also plays a crucial role. In the Murmansk region and the Republic of Karelia, hydropower plants play an important role in the power supply of the northern territories of Russia. Only in the territory of Karelia up to $70 \%$ of all electric energy is generated at hydroelectric power stations. Further development 
of hydro power in the territories of the Russian Barents region is one of the strategic objectives of development of the energy system of Russia.

Russia is one of the most water provided countries of the world. Surface water occupies $12.4 \%$ of the territory of Russia. There are more than 2.5 million rivers in Russia with a total length of 8 million $\mathrm{km}$, at the same time most of them (up to 90\%) are less than 100 $\mathrm{km}$ long. In Russia the economic capacity of small and midget hydroelectric power stations is used approximately for $0.5 \%$ [14].

In the Russian conditions use of energy of small water currents is one of the most effective directions of growth renewable energy market, one of real opportunities a solution of the problem of power supply of the remote energy-deficient regions, its territories occupying up to $40 \%$ where there are no distributive power lines and where delivery of organic fuel is accompanied by great temporary, technical and financial difficulties [15].

The total hydropower potential in the North-West Federal District is estimated at 15 billion $\mathrm{kWh}$. The Republic of Karelia is actively using the hydropower potential. Currently, in the region there are 19 small hydroelectric power stations. In addition, construction of several more hydropower plants with a total capacity more than $150 \mathrm{MW}$ [16].

Solar energy. Solar energy is one of the potential sources of renewable energy. On the one hand, indicators of solar radiation in the territory of the Barents region are estimated as insignificant (about $3 \mathrm{KWh} / \mathrm{m} 2$ a day). On the other hand, the joint use of solar energy with other energy sources (wind and diesel) is very well proven in decentralized power supply systems. This means that in most cases, solar energy is not able to completely replace all other energy sources and become the main source of energy in the countries of the Barents region. At the same time, various combinations of technologies and technical solutions for using solar energy as an auxiliary energy source are actively used in this territory. Solar PV panels and solar collectors are the most common examples.

Since the late 90s, the construction of houses with a "solar" architecture, which reduces the energy consumption of the house, has become widespread in the world and allowed the maximum use of solar energy. The operation of solar collectors of various designs in the Barents region has confirmed the efficiency and allows reducing energy costs for heating. In this case, solar energy is used as a passive source of energy, which, of course, brings good results. The implemented project on the use of solar energy in the Republic of Karelia has shown good energy and economic efficiency - reducing energy consumption by up to $40 \%$ [17].

Power production on the basis of solar energy, also gained distribution not only in the southern territories, but also in northern latitudes. Sharing of solar energy with diesel generators allows receiving significant economy of fuel, moreover, emissions of combustion products into the atmosphere are reduced.

In spite of the fact that in northern latitudes of solar energy it is significantly less, than at the equator, its application is justified and in the north. In the Barents region photoelectric panels gained distribution first of all at power production in the remote settlements which have no central power supply. So in a row the remote settlements of Karelia (the items inVozhmozero, Yustozero, Lindozero, Kimovaara, and Voynitsa) were installed the diesel - solar power stations. As a result of use of this equipment, the cost of one kilowatthour in these settlements fell on average by $35 \%$ [18].

The volume of use of solar energy in the Barents region is currently not significant. Nevertheless, over the past 10 years, the generation volume only in Finland, Sweden and Norway has grown more than 30 times (from $24 \mathrm{MW}$ in 2009 to $728 \mathrm{MW}$ in 2018) [10]. At the same time, the accessibility to the electric grid is much better developed in the EU in the region compared to the Russian part. In the Russian part of the Barents region, the use of solar energy has mainly begun to develop in autonomous energy systems. Since 
currently in remote areas of Karelia, Murmansk, Archangelsk region, as well as in the Komi and Nenets regions, there is still no centralized energy supply.

\section{Conclusion}

The Barents region is an important and strategic region of Europe and the world as a whole. Significant mineral reserves, fish and forest resources are concentrated in this territory. Given the geographical, climatic and geological features, the Barents region is able to make a significant contribution to the development of renewable energy. Today, its potential is only partially used and can be increased several times. The potential amount of renewable energy produced in this territory exceeds the need for energy in the region.

The electric grid of the Barents region do not have enough power to transmit potentially produced energy and to European consumers. Insufficient network capacity is currently a significant deterrent to the further development of renewable energy in this territory. Currently, several high-voltage networks are under construction at once, but their construction requires considerable time - up to five years. After putting them into operation, a larger amount of clean energy generated in the Barents region will be available to consumers from other regions, primarily from Europe.

There are three main steps are necessary to develop the potential of renewable energy in the Russian part of the Barents region. Firstly, it is necessary to debug mechanisms that stimulate energy efficiency. The Russian economy has great potential for energy efficiency growth in almost all sectors. As a priority measure, 100\% metering of the consumption of energy resources is required. This will contribute to the rational use of energy according to the principle "how much you have consumed, you have paid so much." This is an important step, since at present the majority of energy consumers are still not equipped with an energy metering system. This decision, one way or another, will stimulate not only the consumer, but also the energy producer.

The second is the modernization of electrical equipment in autonomous power supply systems. In remote areas, a low-efficiency and expensive diesel generator is still used. It should be replaced by a combined power plant with diesel-renewable energy.

Thirdly, start the construction of a new extensive energy network. This will allow you to breathe new life into the economy of remote areas without the currently available infrastructure. After the implementation of these measures, the next step should be the construction of large power plants to use the potential of renewable energy sources, as is now done in the EU countries of the Barents region.

Renewable energy has significant environmental and economic potential (see Table 4). The use of RES will also contribute to the innovative development of the country. When implementing the concept of energy independence, it is necessary to use a systematic approach. For Russian part of Barents Region on of the way to activation of use of renewable energy is adapting EU experience of use implementation of innovative technologies in this area.

Table 4. Renewable energy potential on North-West Federal District of Russia (Compiled by the authors).

\begin{tabular}{|c|c|c|c|}
\hline Energy resources & Volume & $\begin{array}{c}\text { Oilequivalent/ } \\
\text { mln. tons }\end{array}$ & $\begin{array}{c}\text { Gas equivalent/ } \\
\text { bil. m3 }\end{array}$ \\
\hline Woody biomass & $55.3 \mathrm{mln} . \mathrm{m} 3 /$ year & 9.68 & 10.76 \\
\hline Solid household waste & $5 \mathrm{mln} . \mathrm{tons} /$ year & 0.46 & 0.6 \\
\hline Wind & $1785 \mathrm{bln} . \mathrm{kWh} / \mathrm{year}$ & 153.5 & 169.19 \\
\hline Hydropower energy & $15 \mathrm{bln} . \mathrm{kWh} / \mathrm{year}$ & 1.29 & 1.42 \\
\hline
\end{tabular}




\section{Acknowledgements}

The study was supported by a grant from the Russian Science Foundation, project No. 2118-00500 "Institutional engineering of monocities in the Arctic zone - modernization and sustainable development".

\section{References}

1. IRENA 2018, Global Energy Transformation: A roadmap to 2050, International Renewable Energy Agency (Abu Dhabi, 2018)

2. BP, Statistical Review of World Energy 2019 (London, 2019)

3. S. Tishkov, A. Shcherbak, V. Karginova-Gubinova, A. Volkov, A. Tleppayev, A. Pakhomova, Entrepreneurship and Sustainability Issues 7(4), 3354-3368 (2020) https://doi.org/10.9770/jesi.2020.7.4(51)

4. Comparative table of the calorific value of some fuels (2019) http://ecolesnn.ru/tablitsa-teplotvornosti/

5. P. Druzhinin, A. Shcherbak, S. Tishkov, Studies on Russian Economic Development 3, 280-287 (2018)

6. Supply of Raw Materials, Transport Needs and Economic Potential in Northern Europe (2010) https://norrtagab.se/wp-content/uploads/sites/7/2015/10/ndRA\%CC\%8AVARUANALYS-BARENTS-100428.pdf

7. A. Lyubimov, A. Selivanov, A. Kryuchkov, Izvestia of Samara Scientific Center of the Russian Academy of Sciences 2, 91-94 (2018)

8. Energetic use of biogas solid waste landfill (2020) http://baltfriends.ru/arhiv/rus/publ/renwr/re07.htm

9. Biogas MSW landfill as an energy source (2020) http://srsgroup.su/biogaz-poligonatbo-kak-istochnik-energii.php

10. IRENA 2019, Renewable Energy Statistics 2019, The International Renewable Energy Agency (Abu Dhabi, 2019)

11. S. Purgin, Investicii PFO 8, 30-38 (2006)

12. Windy dollars can fly in to replace the traditional (2019) https://www.kommersant.ru/doc/1297485

13. Prospects for energy renewable resources. Condition of the problem (2020) http://www.spbrc.nw.ru/ru/councils/energetics/special/renewable

14. Hydropower potential of small rivers http://bellona.ru/2008/06/06/gidroenergeticheskj-potentsial-maly

15. E. Akentyeva, G. Sidorenko, G. Tyusov, Trudy Glavnoj Geofizicheskoj Observatorii Im. A.I. Voenkova 570, 95-105 (2014)

16. I. Grigoreva, Energiya Severo-Zapada 8, 2-3 (2018)

17. A. Shcherbak, S. Tishkov, V.V. Karginova-Gubinova, Innovative Technologies in Environmental Science and Education (ITESE-2019), E3S Web Conf. 135, 1-9 (2019) DOI: https://doi.org/10.1051/e3sconf/201913503005

18. Solar power generation is working in Karelia (2019) http://kaeec.org/news/5923.html 